\title{
Application of Synthetic Unit Hydrograph on HEC-HMS Model for Flood Forecasting
}

\author{
Ma Haibo, Dong xin, Chang Wenjuan* \\ (College of Hydraulic \& Environmental Engineering, China Three Gorges University, Yichang 443002,China) \\ The First Author: Ma Haibo, male, Associate Professor, master instructor, doctor, mainly engaged in the study of the direction \\ of hydrology and water resources. \\ Corresponding Author:Chang Wenjuan, female, lecturer, master instructor, doctor, mainly engaged in the study of the \\ direction of hydrology and water resources
}

\begin{abstract}
The surface runoff model of the HEC-HMS hydrological modeling system is mainly simulated through the unit line method. The simulated results usually had big errors because of the flood with different net rainfall magnitude using the same set of unit lines. In this paper, the Huan River Basin was selected as the study area for the flood forecasting using HEC-HMS model. In the process of the HEC-HMS hydrological model construction, the ArcGIS software was used to extract the watershed information according to the river DEM data. The net rainfall was calculated through the initial constant rate loss model. The surface runoff of the basin was calculated by the Snyder unit line model, and the basis was calculated by the exponential decay model. The river flow convergence was calculated by the Muskingum method. Based on the rainfall runoff data of 17 floods, three sets of Snyder unit lines were calculated according to the net rainfall intensity, and then three large, medium and small floods were employed to verify the flow process of the exit section of the basin. The model was calibrated and verified using historical observed data. The results showed that: The determination coefficients and coefficients of agreement for all the flood events were above 0.92 , and the relative errors in peak discharges were all within the acceptable range, which belongs to A-Level forecast. The simulation accuracy of the model in the Huan River basin can be enhanced by synthesizing the Snyder unit line in the HEC-HMS model according to the net rain intensity.
\end{abstract}

\section{Introduction}

The HEC-HMS model is a hydrological simulation system that was developed by the US Army Engineering Corps Hydrology Engineering Center ${ }^{[1]}$, which is a semidistributed hydrological model with physical concepts ${ }^{[2]}$. The model considers the uneven distribution of rainfall and underlying surface distribution, which offers a variety of flow generation, direct runoff, base flow, and convergence calculation methods and which are convenient to apply. So far, when applying the HEC-HMS model to calculate the direct runoff convergence of the ground, the unit line method is often applied. When floods of various net rainfall intensities are predicted, the same set of parameters are used, which existing big error. In this paper, the unit line is applied to obtain the unit line with different net rainfall intensity. When the flood forecasting is carried out, the unit direct line runoff calculation is selected in accordance with the net rain intensity to improve the accuracy of the confluence forecast ${ }^{[3]}$. Meanwhile, when applying the HEC-HMS model to sub- basin, the method of natural watershed is often adopted, which often needs to divide many sub-basins. Thereby, to increase the computational workload. This paper intends to use the Thiessen polygon method to divide the subbasin and to carry out the calculation of runoff yield so that computational efficiency can be improved ${ }^{[4,5]}$.

\section{Research area and data sources}

\subsection{Overview of the research area}

The Huan river is located in the north of the Yangtze River in Hubei Province, at the southern foot of the Dabie Mountains, in Xiaogan City area in the North of Jianghan Plain. The watershed boundary lies between longitude $113^{\circ} 72^{\prime}$ and $114^{\circ} 33^{\prime}$ and latitude $30^{\circ} 86^{\prime}$ and $31^{\circ} 89$. The main stream is $8 \mathrm{~km}$, and the drainage area is $2590.88 \mathrm{~km}^{2}$. Watershed topography is high in northeast and low in southwest. The landform is mainly hilly and mountainous. The northeast is a low mountain area with the height from $500 \mathrm{~m}$ to $1000 \mathrm{~m}$ and low hills in the

Corresponding Author: Email: cwj1116@126.com

Email: mahaibo@ctgu.edu.dn 
southwest with the height from $100 \mathrm{~m}$ to $500 \mathrm{~m}$. The basin is a subtropical monsoon climate with abundant rainfall, with annual precipitation ranging from $1040 \mathrm{~mm}$ to 1230 mm. $70 \%$ precipitation is concentrated in April to 9 September. The largest flood measured in history is in July
17, 1996, with peak flow of $60606060 \mathrm{~m}^{3} / \mathrm{s}$ and $\mathrm{s} 39.95$ $\mathrm{m}$ flood-peak stage. The elevation map of the river basin is shown in Fig. 1.

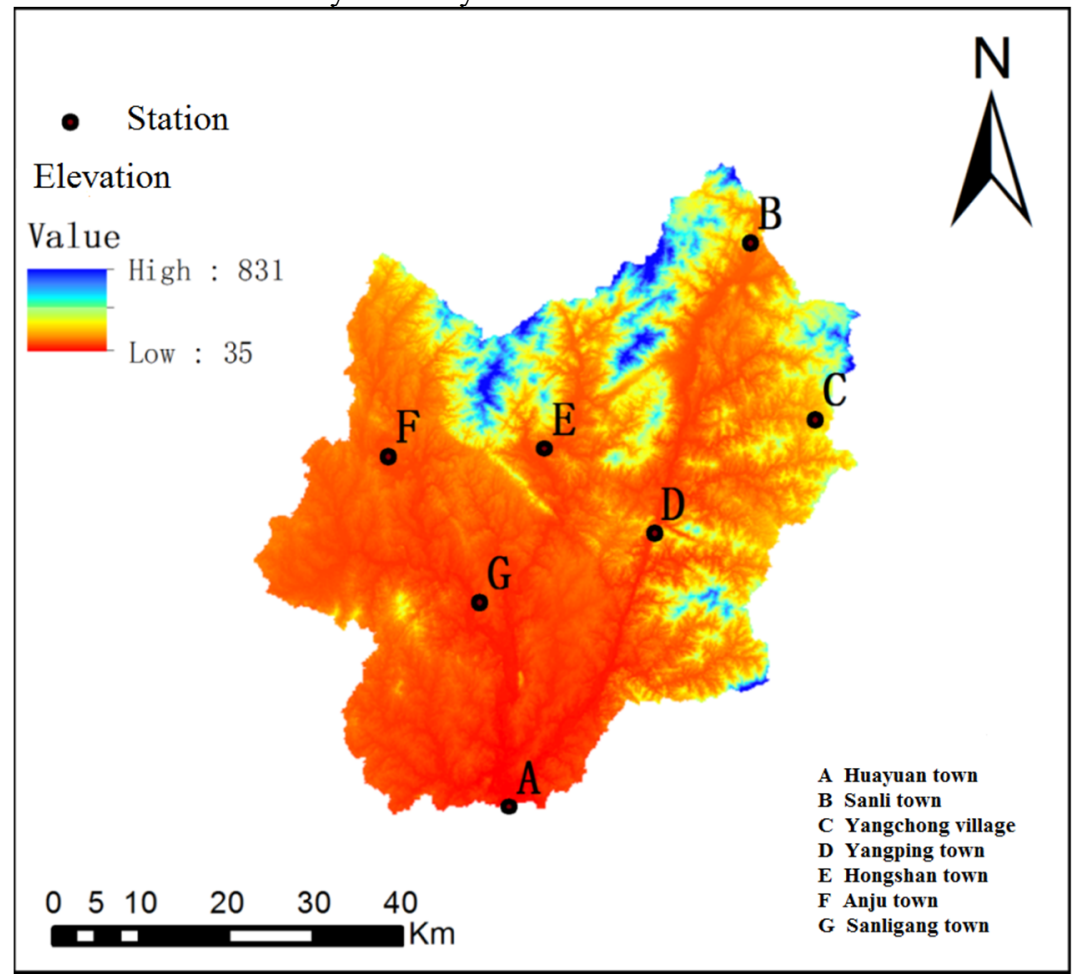

Fig.1 Huan River Basin elevation map

\subsection{Basic data}

The research data of the basin includes: Using the 1:100,000-scale land use status remote sensing monitoring data provided by the Resource and Environmental Science Data Center of the Chinese Academy of Sciences, sing the Hydrological Yearbook to find rainfall runoff data for seven rainfall stations from 1969 to 1989 and evaporation data, NASA provided 90m SRTM digital elevation data.

\section{Research methods}

\subsection{Establishment of watershed models}

In this paper, the basin background map was generated by GIS, and the basin was divided into 7 sub-basins by Tyson polygon method. The hydrological units such as the subbasin, river and confluence point were added to the basin background map, and the watershed model map was established as shown in Fig.2. The sub-basin area was shown in Table 1. 


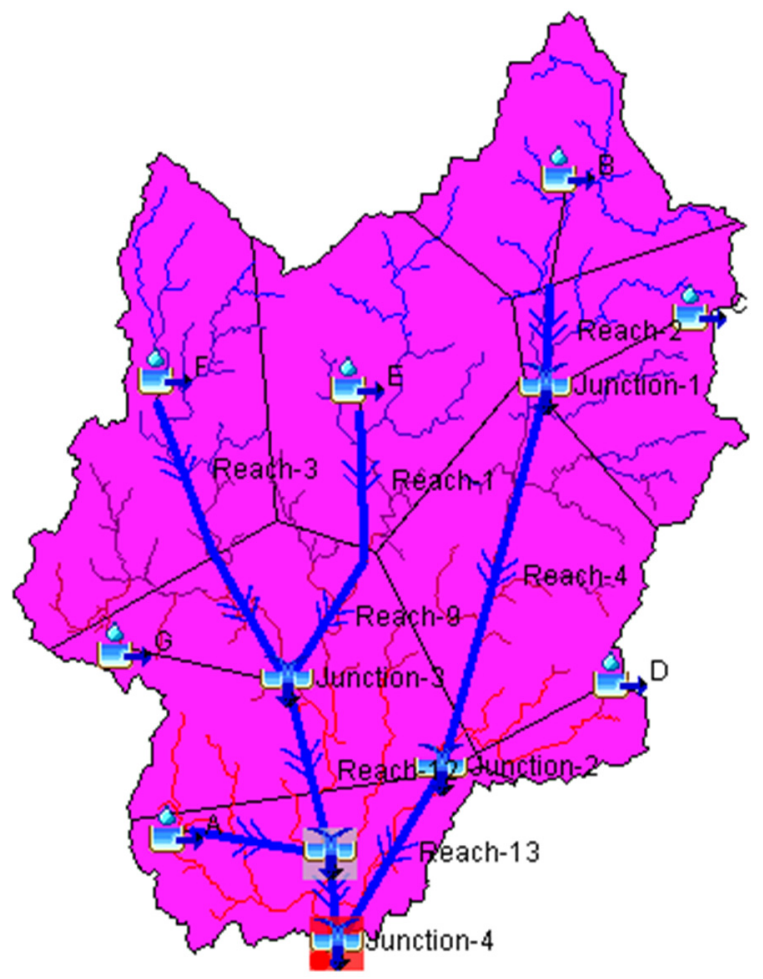

Fig.2 Schematic diagram of the HEC-HMS

Table 1 Sub-basin area and weight

\begin{tabular}{ccc}
\hline Sub basin & Area $\left(\mathrm{Km}^{2}\right)$ & Weights \\
A & 259.96 & 10.03 \\
B & 269.74 & 10.41 \\
C & 272.75 & 10.53 \\
D & 464.89 & 17.94 \\
E & 410.06 & 15.83 \\
F & 433.36 & 16.73 \\
G & 480.12 & 18.53 \\
The total area & 2590.88 & 1 \\
\hline
\end{tabular}

\subsection{Computational model of runoff volume}

The initial constant rate loss method was employed to simulate the runoff process. The initial constant rate loss method means that the maximum potential rainfall loss $f_{c}$ constant throughout the rainfall process.

The net rainfall $p e_{t}$ this period was given by formula 1.

$$
p e_{t}=\left\{\begin{array}{cc}
0 & \text { If } \sum P_{i}<I_{a} \\
P_{t}-f_{c} & \text { If } \sum P_{i}>I_{a} \text { and } P_{t}>f_{c} \\
0 & \text { If } \sum P_{i}>I_{a} \text { and } P_{t}<f_{c}
\end{array}\right\}
$$

In the formula: $\sum P_{i}$ is the cumulative rainfall; $P_{t}$ is the rainfall intensity

To indicate interception and pothole filling, the constant $I_{a}$ added to the initial loss. Water interception is a part of rainfall interception in catchment area, including vegetation. Filling water is the loss of rainfall caused by the change of the topography of catchment area. The sum of these two parts is the initial loss, which occurred before the surface runoff.

\subsection{Surface runoff model}

In this paper, the Snyder unit line model was applied to simulate the surface runoff process of clear rain in catchment area ${ }^{[6]}$. The peak flow delay, peak flow and total time datum were selected as the eigenvalues of unit line for the model. Among them, the relation between rainfall duration and peak flow latency, as shown in formula (2).

$$
t_{p}=5.5 t_{r}
$$

In the formula: $t_{r}$ is the rainfall duration; $t_{p}$ is peak flow latency

Delay per unit line of precipitation per unit area and the peak value of unit line in unit area can be associated with the following formula (3)

$$
\frac{U_{p}}{A}=C \frac{C_{p}}{t_{p}}
$$

In the formula: $U_{p}$ is the peak value of the standard unit line; $\mathrm{A}$ is the drainage area of the catchment; $C_{p}$ is peak coefficient of unit line. $\mathrm{C}$ is the conversion constant (the unit system for SI is 2.75 and the unit system for a pound of feet is 640).

In the model, the peak flow latency $t_{p}$ and the peak coefficient of unit line $C_{p}$ were needed to be determined. Because the unit line of different rain intensity had peak flow latency, in order to improve the accuracy of forecast, in this paper, the method of classification and synthesis was used to set the parameters according to the magnitude of rain intensity. 


\subsection{Base flow model}

The exponential decay model was employed to calculate the base flow of secondary flood. The model was generally used to describe the natural drainage process of watershed water storage. Base flow $Q_{t}$ Defined at the time of this model was shown in formula (4).

$$
Q_{t}=Q_{0} k^{t}
$$

In the formula: $Q_{0}$ is the initial discharage; $\mathrm{k}$ is the exponential recession constant.

\subsection{River flow model}

Muskinggen method was applied in the calculation of river confluence ${ }^{[7]}$. The calculation formula of the method as follows:

$$
\begin{aligned}
Q_{t}=\frac{\Delta t-2 K X}{2 K(1-X)}+\Delta t & I_{t}+\frac{\Delta t+2 K X}{2 K(1-X)+\Delta t} I_{t-1} \\
& +\frac{2 K(1-x)-\Delta t}{2 K(1-X)+\Delta t} Q_{t-1}
\end{aligned}
$$

In the formula: $Q_{\mathrm{t}}$ is the discharge of the section at $\mathrm{T}$ moment; $\Delta t$ is the period length of simulated rainfall runoff process of the model.

$\mathrm{K}$ is the travel time when the upward flow is a constant flow; $\mathrm{X}$ is the flow specific gravity factor. $I_{t}$ is the inflow discharge of the cross section at T moment; $I_{t-1}$ is inflow of the upper end face at $\mathrm{t}-1$ moment; $Q_{t-1}$ is the outflow of the lower section at t-1 moment;

\section{Results and analysis}

The parameters in the HMS model include: constant osmotic rate fc, peak flow delayed time $t_{p}$, peak coefficient $C_{p}$, peak flow threshold, recession coefficient $\mathrm{k}$, drain constant $\mathrm{k}$ and flow specific gravity factor $\mathrm{x}$. In this paper, 21 floods from 1969 to 1989 were used for the analysis of watershed runoff, taking 19 floods as the parameter rate of HMS model. The model was calibrated and verified using the other three historical flood, the model suitable parameters for the river basin were obtained. The results were shown in Table 6-10. In this paper, the influence of different net rainfall on Snyder unit line was considered for rainfall runoff relation in Huan river base, the net rainfall was divided into three groups and each group was corresponding to a peak flow latency . The accuracy of the regular simulation of the model rate was shown in Table 11. The accuracy of the prediction for the verification period was shown in Table 12. The predicted flow duration curve in the verification period was shown in Fig. 3

Table 6 Parameters of the Muskingen model

\begin{tabular}{ccc}
\hline Reach & Parameters & $\begin{array}{c}\text { Optimized } \\
\text { parameter value }\end{array}$ \\
\hline Reach-1 & $\mathrm{K}$ & 5.314 \\
Reach-1 & $\mathrm{X}$ & 0.347 \\
Reach-2 & $\mathrm{K}$ & 1.719 \\
Reach-2 & $\mathrm{X}$ & 0.332
\end{tabular}

\begin{tabular}{|c|c|c|}
\hline $\begin{array}{c}\text { Sub } \\
\text { basin }\end{array}$ & Parameters & $\begin{array}{c}\text { Optimized } \\
\text { parameter value }\end{array}$ \\
\hline $\begin{array}{c}\text { A } \\
\text { basin }\end{array}$ & Peaking coefficient & 0.220 \\
\hline $\begin{array}{c}\text { B } \\
\text { basin }\end{array}$ & Peaking coefficient & 0.185 \\
\hline $\begin{array}{c}\mathrm{C} \\
\text { basin }\end{array}$ & Peaking coefficient & 0.214 \\
\hline $\begin{array}{c}\mathrm{D} \\
\text { basin }\end{array}$ & Peaking coefficient & 0.218 \\
\hline $\begin{array}{c}\mathrm{E} \\
\text { basin }\end{array}$ & Peaking coefficient & 0.225 \\
\hline $\begin{array}{c}F \\
\text { basin }\end{array}$ & Peaking coefficient & 0.218 \\
\hline $\begin{array}{c}\mathrm{G} \\
\text { basin }\end{array}$ & Peaking coefficient & 0.197 \\
\hline
\end{tabular}

\begin{tabular}{lll} 
Reach-3 & K & 4.002 \\
Reach-3 & X & 0.340 \\
Reach-4 & K & 6.383 \\
Reach-4 & X & 0.322 \\
Reach-5 & K & 1.705 \\
Reach-5 & X & 0.323 \\
Reach-7 & K & 1.536 \\
Reach-7 & X & 0.330 \\
Reach-8 & K & 5.330 \\
Reach-8 & X & 0.300 \\
Reach-9 & K & 4.548 \\
Reach-9 & X & 0.352 \\
Reach-12 & K & 1.825 \\
Reach-12 & X & 0.339 \\
Reach-13 & K & 3.590 \\
Reach-13 & X & 0.332 \\
\hline
\end{tabular}

Table 7 Parameters of Snyder's UH

\begin{tabular}{|c|c|c|}
\hline $\begin{array}{c}\text { Sub } \\
\text { basin }\end{array}$ & Parameters & $\begin{array}{c}\text { Optimized } \\
\text { parameter value }\end{array}$ \\
\hline $\begin{array}{c}\mathrm{A} \\
\text { basin }\end{array}$ & The threshold value & 0.156 \\
\hline $\begin{array}{c}\text { A } \\
\text { basin }\end{array}$ & Recession constant & 0.492 \\
\hline $\begin{array}{l}\text { B } \\
\text { basin }\end{array}$ & The threshold value & 0.158 \\
\hline $\begin{array}{l}\mathrm{B} \\
\text { basin }\end{array}$ & Recession constant & 0.478 \\
\hline $\begin{array}{c}\mathrm{C} \\
\text { basin }\end{array}$ & The threshold value & 0.160 \\
\hline $\begin{array}{c}\mathrm{C} \\
\text { basin }\end{array}$ & Recession constant & 0.483 \\
\hline $\begin{array}{c}\mathrm{D} \\
\text { basin }\end{array}$ & The threshold value & 0.137 \\
\hline $\begin{array}{c}\mathrm{D} \\
\text { basin }\end{array}$ & Recession constant & 0.490 \\
\hline $\begin{array}{c}\mathrm{E} \\
\text { basin }\end{array}$ & The threshold value & 0.159 \\
\hline $\begin{array}{c}\mathrm{E} \\
\text { basin }\end{array}$ & Recession constant & 0.499 \\
\hline
\end{tabular}

Table 8 Parameters of the exponential recession model 


\begin{tabular}{clc} 
F & The threshold value & 0.185 \\
$\begin{array}{c}\text { basin } \\
\text { F } \\
\text { basin }\end{array}$ & Recession constant & 0.490 \\
$\begin{array}{c}\text { G } \\
\text { basin }\end{array}$ & The threshold value & 0.139 \\
basin & Recession constant & 0.467 \\
\hline
\end{tabular}

Table 9 Initial constant rate loss model parameter optimization table

\begin{tabular}{ccc}
\hline $\begin{array}{c}\text { Sub- } \\
\text { basin }\end{array}$ & Parameters & $\begin{array}{c}\text { Optimized parameter } \\
\text { average(in } / \mathrm{h})\end{array}$ \\
\hline $\begin{array}{c}\text { A } \\
\text { basin } \\
\text { B } \\
\text { basin }\end{array}$ & Constant Rate & 0.228 \\
& Constant Rate & 0.225
\end{tabular}

\begin{tabular}{clc}
$\mathrm{C}$ & Constant Rate & 0.202 \\
$\begin{array}{c}\text { basin } \\
\mathrm{D}\end{array}$ & Constant Rate & 0.225 \\
$\begin{array}{c}\text { basin } \\
\mathrm{E}\end{array}$ & Constant Rate & 0.199 \\
$\begin{array}{c}\mathrm{F} \\
\text { basin }\end{array}$ & Constant Rate & 0.200 \\
$\begin{array}{c}\mathrm{G} \\
\text { basin }\end{array}$ & Constant Rate & 0.228 \\
\hline
\end{tabular}

Table 10 Correspondence between flood peak delay and net rainfall

\begin{tabular}{cc}
\hline Net rainfall $($ in $)$ & Standard lag \\
\hline$(0,2.74)$ & 2 \\
$(2.74,3.03)$ & 4 \\
$(3.03,+\infty)$ & 5 \\
\hline
\end{tabular}

Table 11 Model rate determination

\begin{tabular}{|c|c|c|c|c|c|}
\hline \multirow{2}{*}{ Number } & \multicolumn{2}{|c|}{$\begin{array}{c}\text { Start and end time } \\
\text { (year - month - day) }\end{array}$} & \multicolumn{3}{|c|}{ Runoff depth / (mm) } \\
\hline & $\begin{array}{l}\text { Starting } \\
\text { time }\end{array}$ & $\begin{array}{l}\text { End } \\
\text { Time }\end{array}$ & $\begin{array}{c}\text { Analog } \\
\text { error }\end{array}$ & $\begin{array}{l}\text { License } \\
\text { error }\end{array}$ & Evaluate \\
\hline 1 & $1970-5-26$ & $\begin{array}{c}1970-6- \\
4\end{array}$ & -25.9 & 18.7 & $\mathrm{~F}$ \\
\hline 2 & $1971-5-1$ & $\begin{array}{l}1971-5- \\
9\end{array}$ & -3.21 & 9.96 & Q \\
\hline 3 & $1971-6-24$ & $\begin{array}{l}1971-7- \\
7\end{array}$ & -1.13 & 16.2 & Q \\
\hline 4 & $1972-5-11$ & $\begin{array}{c}1972-5- \\
22\end{array}$ & -5.16 & 7.04 & Q \\
\hline 5 & $1974-4-11$ & $\begin{array}{c}1974-4- \\
17\end{array}$ & 9.75 & 3.78 & $\mathrm{~F}$ \\
\hline 6 & $1974-8-2$ & $\begin{array}{l}1974-8- \\
9\end{array}$ & 1.67 & 5.96 & Q \\
\hline 7 & $1975-7-8$ & $\begin{array}{l}1975-7- \\
19\end{array}$ & -0.75 & 18.3 & Q \\
\hline 8 & $1975-10-9$ & $\begin{array}{l}1975- \\
10-20\end{array}$ & -1.13 & 8.04 & Q \\
\hline 9 & $1976-7-14$ & $\begin{array}{c}1976-7- \\
25\end{array}$ & 2.37 & 14.46 & Q \\
\hline 10 & $1977-7-15$ & $\begin{array}{l}1977-7- \\
25\end{array}$ & 13.44 & 14.71 & Q \\
\hline 11 & $1982-8-17$ & $\begin{array}{l}1982-8- \\
31\end{array}$ & 15.1 & 19.43 & Q \\
\hline 12 & $1983-7-21$ & $\begin{array}{l}1983-7- \\
31\end{array}$ & -4.92 & 34.55 & Q \\
\hline 13 & 1983-9-15 & $\begin{array}{l}1983-9- \\
27\end{array}$ & -4.48 & 11.15 & Q \\
\hline 14 & 1984-7-16 & $\begin{array}{l}1984-7- \\
27\end{array}$ & 9.47 & 12.73 & Q \\
\hline 15 & $1985-5-2$ & $\begin{array}{l}1985-5- \\
11\end{array}$ & 8.09 & 13.29 & Q \\
\hline 16 & $1987-4-30$ & $\begin{array}{l}1987-5- \\
10\end{array}$ & -0.27 & 13.41 & Q \\
\hline 17 & $1987-7-19$ & $\begin{array}{c}1987-7- \\
27\end{array}$ & -3.94 & 8.22 & Q \\
\hline \multicolumn{6}{|c|}{ Table 12 Flood forecasting results evaluation } \\
\hline \multirow[t]{2}{*}{$\begin{array}{c}\text { Flood } \\
\text { sequence }\end{array}$} & \multicolumn{2}{|c|}{ Runoff depth } & $\begin{array}{c}\text { Runoff } \\
\text { depth }\end{array}$ & \multicolumn{2}{|r|}{$\begin{array}{l}\text { Relative } \\
\text { error }\end{array}$} \\
\hline & \multicolumn{2}{|c|}{$\mathrm{mm}$} & $\mathrm{mm}$ & \multicolumn{2}{|r|}{$\%$} \\
\hline 198708 & \multicolumn{2}{|c|}{32.51} & 33.75 & \multicolumn{2}{|r|}{-3.67} \\
\hline 198705 & \multicolumn{2}{|c|}{79.85} & 72.4 & \multicolumn{2}{|r|}{-10.29} \\
\hline 198207 & \multicolumn{2}{|c|}{75.55} & 78.34 & \multicolumn{2}{|r|}{-3.56} \\
\hline
\end{tabular}

Table13 Flood peak forecasting results evaluation

\begin{tabular}{cccc}
\hline Flood & $\begin{array}{c}\text { Simulation } \\
\text { of flood } \\
\text { peak } \\
\text { sequence }\end{array}$ & $\begin{array}{c}\text { The } \\
\text { measured } \\
\text { peak }\end{array}$ & $\begin{array}{c}\text { Relative } \\
\text { error }\end{array}$ \\
& $\mathrm{m}^{3} / \mathrm{s}$ & $\mathrm{m}^{3} / \mathrm{s}$ & $\%$ \\
\hline 197105 & 762 & 751 & 1.46
\end{tabular}

\begin{tabular}{|c|c|c|c|c|c|c|}
\hline \multicolumn{3}{|c|}{ Flood-peak discharge $/\left(\mathrm{m}^{3} \cdot \mathrm{s}^{-1}\right)$} & \multicolumn{3}{|c|}{ Peak time $/ \mathrm{h}$} & \multirow[t]{2}{*}{ DC } \\
\hline $\begin{array}{c}\text { Analog } \\
\text { error }\end{array}$ & $\begin{array}{l}\text { License } \\
\text { error }\end{array}$ & Evaluate & $\begin{array}{c}\text { Analog } \\
\text { error }\end{array}$ & $\begin{array}{l}\begin{array}{l}\text { License } \\
\text { error }\end{array}\end{array}$ & Evaluate & \\
\hline-1593.62 & 528.22 & F & 6 & 3 & F & 0.615 \\
\hline 5.21 & 116.25 & Q & 1 & 3 & Q & 0.974 \\
\hline-76.24 & 188.68 & Q & 2 & 3 & $\mathrm{Q}$ & 0.936 \\
\hline-19.17 & 103.83 & Q & 3 & 3 & Q & 0.858 \\
\hline 4.8 & 117.2 & Q & 1 & 3 & Q & 0.763 \\
\hline 30.31 & 185.6 & Q & 3 & 3 & Q & 0.921 \\
\hline-422.83 & 526.22 & Q & 4 & 3 & $\mathrm{~F}$ & 0.922 \\
\hline-33.75 & 126 & Q & 4 & 3 & $\mathrm{~F}$ & 0.857 \\
\hline-730.14 & 410 & $\mathrm{~F}$ & 0 & 3 & Q & 0.674 \\
\hline-236.82 & 240 & Q & 6 & 3 & $\mathrm{~F}$ & 0.842 \\
\hline-494.72 & 218 & $\mathrm{~F}$ & 3 & 3 & Q & 0.485 \\
\hline-29.74 & 588.24 & Q & 0 & 3 & Q & 0.929 \\
\hline-243.18 & 274.2 & Q & 1 & 3 & Q & 0.932 \\
\hline-118.98 & 220.09 & Q & 1 & 3 & Q & 0.899 \\
\hline 57.14 & 258 & Q & 0 & 3 & Q & 0.88 \\
\hline-6.56 & 399.31 & Q & 1 & 3 & Q & 0.91 \\
\hline \multirow[t]{3}{*}{0.7} & 244.2 & Q & 1 & 3 & Q & 0.984 \\
\hline & 198705 & \multicolumn{2}{|c|}{2346.96} & 2270 & \multicolumn{2}{|c|}{3.39} \\
\hline & 198207 & \multicolumn{2}{|c|}{699.07} & 725.3 & \multicolumn{2}{|c|}{1.36} \\
\hline
\end{tabular}

Table 14 Peak time and deterministic coefficient

\begin{tabular}{cccc}
\hline $\begin{array}{c}\text { Flood } \\
\text { sequence }\end{array}$ & $\begin{array}{c}\text { Flood peak } \\
\text { time error } \\
\mathrm{h}\end{array}$ & DC & $\begin{array}{c}\text { Precision } \\
\text { grade }\end{array}$ \\
\hline 197105 & 1 & 0.948 & $\mathrm{~A}$ \\
198705 & 1 & 0.964 & $\mathrm{~A}$ \\
198207 & 0 & 0.924 & $\mathrm{~A}$ \\
\hline
\end{tabular}

The simulation results were shown in Fig. 3.

For three different rainfalls, three different unit lines were used to simulate rainfall runoff in the basin, and the 
simulation results were all A-level forecasts. The results show that HEC-HMS can better predict floods by using different unit lines in the Huan River Basin.
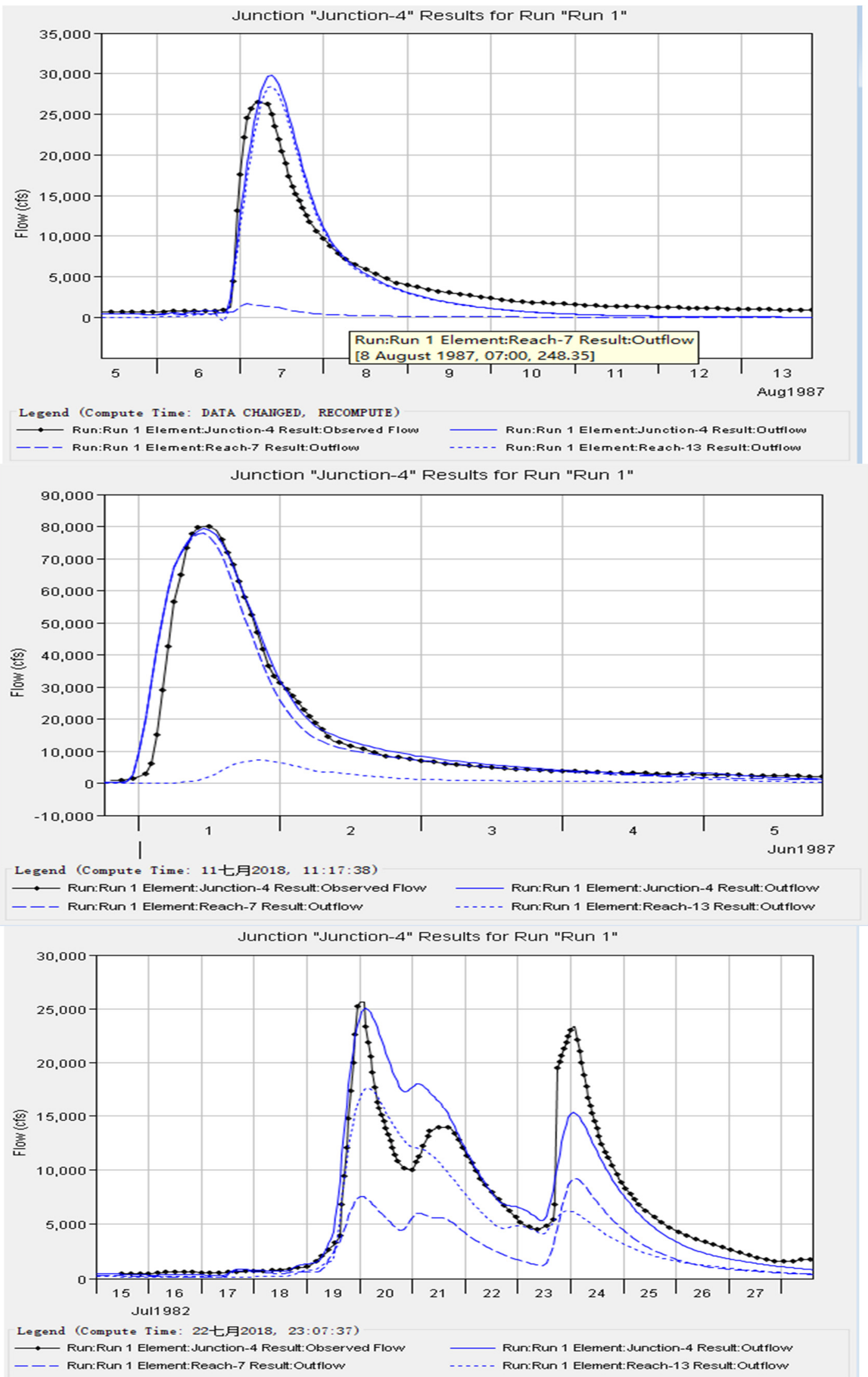

Fig.3 Comparison of simulated flood with measured flood 


\section{Conclusion}

The method of Tyson polygon was used to calculate the yield and confluence of sub-watersheds, the number of sub-basins divided was less, the simulation precision can meet the requirements, and the efficiency of calculation can be improved.

In the Huan river basin, Integration of unit lines according to the size of the secondary flood clean rain could improve the accuracy of flood forecasting. The HEC-HMS model could effectively apply forecast the secondary flood in the river basin. The HEC-HMS hydrological model was suitable for hydrology simulation in the study area.

\section{Funding information:}

The author would like to thank the jointly supported by National Key Research and Development Project (2017YFC0405606, 2017YFC0405603), the National Natural Science Foundation of China (51709151), and the Open Research Fund of State Key Laboratory of Simulation and Regulation of Water Cycle in River Basin (China Institute of Water Resources and Hydropower Research), Grant NO:IWHR-SKL-201704.

\section{References}

1. Li X, He H. HEC-HMS Hydrological Modeling System.China Water \& Power Press:Beijing China,2014.

2. Yan H,Wang C,Wen P. Overview of Studies on Distributed Hydrological Model. Water Resources and Power.2008,26(6):2-4

3. Zhou F,Cui J. Expounding for Predicting the Flood Processing in the Outlet of the Basin with the Unit Line Method.2005,8:5-7.

4. Long Y, Liao Z.Surface precipitation calculation of Qingyang area based on Thiessen polygons method. Journal of Hebei University of Engineering (Natural Science Edition) .2005, 29 :65-67.

5. Yan $\mathrm{Z}, \mathrm{Mu} \mathrm{G}$ Surface Precipitation Calculation of River Basin Based on Thiessen Polygons Method.2017,23:19-22.

6. LINSLEY R K, KOHLER M A, PAULHUS J L H. Hydrology for Engineers. McGraw-Hill, New York 1982: 223-225.

7. Xu Z.Application of Muskingum Flood Rooting Method . Journal of North China Institute of Water Conservancy and Hydroelectric Power .26(4):1-3

8. Reshma T, Sundara Kumar P, Ratna Kanth Babu MJ, Sundara Kumar KSimulation of runoff in watersheds using SCS-CN and Muskingum-Cunge methods using remote sensing and geographical information systems. 2010. Vol 25:31-42.

9. Razi MAM, Ariffin J, Tahir W, Arish NAM Flood estimation studies using hydrologic modeling system
(HEC-HMS) for Johor river, Malaysia. J Applied Sci .2010,10(11):930-939.

10. Mishra SK, Jain MK, Singh VP .Evaluation of SCS CN-based model incorporating antecedent moisture. Water Resour Manag 2010,18(6):567-589.

11. Halwatura, D.; Najim, M. Application of the HECHMS model for runoff simulation in a tropical catchment. Environ. Model. Softw. 2013, 46, 155162.

12. Feldman, A.D. Hydrologic Modeling System HECHMS, Technical Reference Manual. U.S. Army Corps of Engineers, Hydrologic Engineering Center, HEC,Davis, CA, USA.2010.

13. Fleming M, Scharffenberg W, Hydrologic Modeling System (HEC-HMS):New Features for Urban Hydrology.Hydraulic Engineer, USACE HydrologicEngineering Center, Davis, CA.2010.

14. Cydzik K, Hogue TS Modeling postfire response and recovery using the hydrologic engineering center hydrologic modeling system (HEC-HMS). J Am Water Res Assoc.2009, 45:702-714.

15. Knebl MR, Yang ZL, Hutchison K, Maidment DR Regional scale flood modeling using NEXRAD rainfall, GIS, and HEC-HMS/RAS: a case study for the San Antonio River Basin Summer 2002 storm event. J Environ Manage .2009,75:325-336.

16. Verma AK, Jha MK, Mahana RK Evaluation of HEC-HMS and WEPP for simulating watershed runoff using remote sensing and geographical information system. Paddy Water Environ.2009, 8:131-144.

17. Yusop Z, Chan CH, Katimon A Runoff characteristics and application of HEC-HMS for modelling stormflow hydrograph in an oil palm catchment. Water Sci Technol .2009,56:41-48.

18. Al-Abed N, Abdulla F, Abu Khyarah A GIShydrological models for managing water resources in the Zarqa River basin. Environ Geol.2009, 47:405411.

19. Knebl, M.R.; Yang, Z.L.; Hutchison, K.; Maidment, D.R. Regional scale flood modeling using NEXRAD rainfall, GIS, and HEC-HMS/RAS: A case study for the San Antonio River Basin, Summer 2002 storm event. J. Environ. Manag. 2005,75, 325-336.

20. Eyad, A.; Broder, M. Modelling rainfall runoff relations using HEC-HMS and IHACRES for a single rain event in an arid region of Jordan. Water Resour. Manag. 2013, 27, 2391-2409.

21. Fares, L.; Rachid, M. Comparison of WBNM and HEC-HMS for runoff hydrograph prediction in a small urban catchment. Water Resour. Manag. 2015, 29, 2485-2501.

22. Yusop Z, Chan CH, Katimon A Runoff characteristics and application of HEC-HMS for modelling stormflow hydrograph in an oil palm catchment. Water Sci Technol.2007,56:41-48.

23. Bournaski E,Iliev R,Kirilov L HEC-HMS modelling of rainstorm in a catchment. The mesta 
case study. C R Acad Bulg Sci.2009 62:1141-1146.

24. Chu XF,Steinman A. Event and continuous hydrologic modeling with HEC-HMS. J Irrig Drain E-ASCE 2009,135:119-124.

25. Cydzik K, Hogue TS.Modeling post fire response and recovery using the hydrologic engineering center hydrologic modeling system(HEC-HMS). J Am Water Res Assoc.2009, 45:702-714.

26. Tiwari KN, Kanan N, Singh RD, Ghosh SK. Watershed parameters extraction using GIS and remote sensing for hydrologic modeling.Asianpacific Remote Sensing GIS J .1997,10(1):43-52.

27. Liang, R. Application of HEC-HMS in the Beizhangdian Watershed; Tai Yuan University of Technology: Tai Yuan, China, 2012.

28. Gao, Y.; Yuan, Y.; Wang, H.; Schmidt, A.R.; Wang, K.; Ye, L. Examining the effects of urban agglomeration polders on flood events in Qinhuai river basin, china with HEC-HMS model. Water Sci. Technol. 2017, 75, 2130-2138.

29. Meenu, R.; Rehana, S.; Mujumdar, P.P. Assessment of hydrologic impacts of climate change in TungaBhadra basin, India with HEC-HMS and SDSM. Hydrol. Process. 2013, 27, 1572-1589.

30. Liang R. Application of HEC-HMS in the Beizhangdian Watershed; Tai Yuan University of Technology: Tai Yuan, China, 2012.

31. Li Q. Changing of Spatial Pattern and the Hydrological Response of Urbanization in Qinhuai River Basin; Nanjing University: Nanjing, China, 2012.

32. Scharffenberg WA, Fleming MJ Hydrologic modeling system HEC-HMS user manual version 3.5. US Army Corps of Engineers, Hydrologic Engineering Center, Davis, CA., USA.2010. 